\title{
RETAIL LANDSCAPING IN INDIA - CHALLENGES AND STRATEGIES
}

\begin{tabular}{|c|}
\hline Prof. Dr. Arcot Purna Prasad \\
Associate Professor, Institute of Management, \\
Christ University, Bengaluru \\
Email: arcot.prasad@ christuniversity.in \\
\hline
\end{tabular}

\section{INTRODUCTION}

\section{"Buy at low and sell at high"}

It is the mantra of trading in every field. The difference between selling price and buying price is called margin from trader's perspective. More margins attract more players and fewer margins are the result of severe competition. From abnormal to thin wafer margins business will travel. At one level it may become under costing to keep some players out of competition. Competition driven markets will constantly think of innovations which will help their customers and ultimately organization at large. When waters are calm disruptive innovation will break the backbone of the legacies and create a new game which is full of turbulences. Competition has surpassed all levels and now companies are focusing on supply chains. Competition is among supply chains have started. It is the time to look at the mirror critically and identify our strengths and develop those first. Weakness is outsourced or buried under deep soil. Now there is no point in worrying too much about our weaknesses. In the language of operations we are challenging our own existing processes and systems to rediscover and redefine our future business. In this context retailing has taken lot of shapes in the history and it will be a different proposition game in the future. Supply chain cost is transferred on to poor customers. Literally customers are

Today's supply chain management can be 
defined as a combination of SRM, ERP and

CRM. In this SRM is about Suppliers

Relationship Management is coupled with ERP (Enterprise Resource Planning.

Every company should feel that Suppliers

are the extended version of the company and really quality management starts at supplier's place. Inventory cost can be controlled by having balanced strategic alliance with suppliers to develop Vendor Managed Inventory(VMI) which can be converted to JIT (Just in Time).On other hand in the customer direction pull can be adopted to reduce finished goods inventory and work in process inventory will the only area of concern. If inventory cost can be controlled then product or services becomes cheaper by $30 \%$ to $35 \%$. Today supply chains are chased by VUCA (Volatility, Uncertainty Complexity and Ambiguity). Retailing is the important ingredient of the supply chain. It can be either B2B (Business to Business) or $\mathrm{B} 2 \mathrm{C}$ (Business to Customers).

BCG reports as shown below, depicts that returns are good but is coupled with volatility. These are conflicting to be managed with better management strategies. 


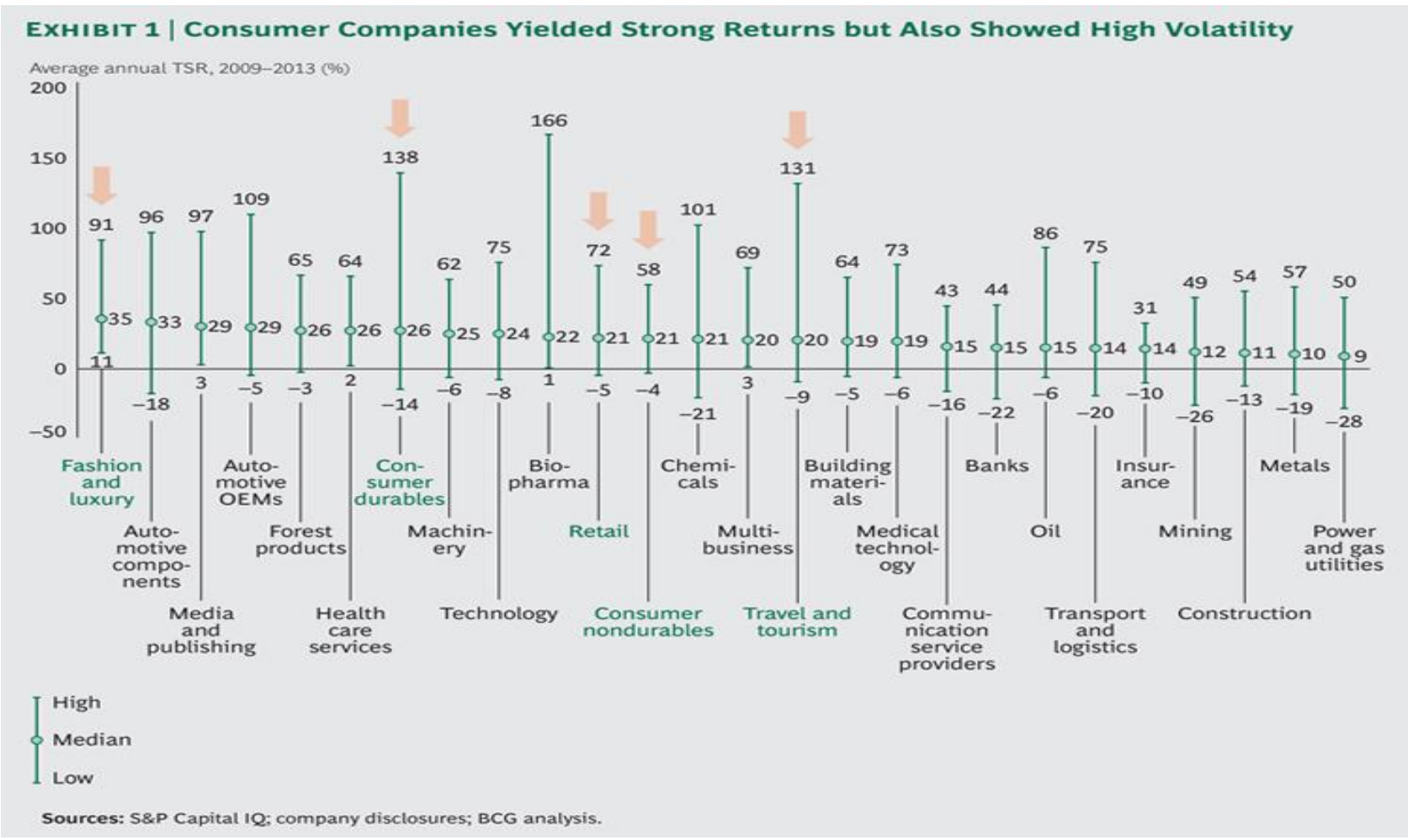

\section{Present Retailing Scenario in India}

Indian retail trade is currently in a transformational stage. As per the industry data available on the public domain, the Indian retail industry accounts for about 1415 per cent of the GDP of the country.

\section{Market size of Indian Retail}

- The Indian retail industry is valued to be currently worth around US\$ 500 billion. As per the estimates of the Department of Consumer Affairs, the domestic retail market is projected to be worth US\$ 1.3 trillion by 2020. McKinsey Global

Institute predicted that India's consumer market would be worth US\$ 1.5 trillion by 2025 , surpassing Germany to become the fifth largest economy (behind the US, Japan, China and the UK) in the world. Almost 90 per cent of the Indian retail sector is controlled by tiny familyrun shops (i.e. the unorganized segment).

- The unorganized retail stores are very small in size. Kamal and Kumar cites that out of 14 million outlets situated in 
the country only $4 \%$ have space larger than 500 sq.ft. As per the estimates, there are 11 retail outlets for every 1000 people. A majority of unorganized retail outlets are managed by family members. The unorganized retailers cannot reduce their inventory procurement costs as they procure their wares from middle men who take a large commission and all their payment is through cash transactions.

- The concept of organized retail is formed on the basis of four principles that were found lacking in the unorganized retail sector. The four principles are Customer Orientation, Coordinated effort, Value driven and Goal orientation.

- In a study conducted by ICRIER in 2010 revealed the share of India's organized retail to be about $8 \%$ which is comparatively very low than countries like USA (85\%), UK, France, Germany, Spain, Taiwan $(75 \%-80 \%)$, Japan, South Africa $(67 \%-70 \%)$. It was estimated from that India had tremendous potential for growth and it is expected to reach $15 \%$ of the total market share in the next 5 years.

- Sikri and Wadhwa reports that the revenue generated from organized retail was $\$ 15.5$ billion in $2009, \$ 41.4$ billion in 2012 and would be $\$ 94.8$ billion in 2019.

\section{Major Retail Segments in India}

Organized retail in India can be segmented in two ways - segmentation by verticals and by channels. Verticals are segmented on the basis of the type of merchandise offered; similar merchandise can be clubbed together to form a vertical, for instance food and grocery. Channels are the means through which retailers sell their merchandise; for example, store channels of retailing that 
ELK Asia Pacific Journals - Special Issue ISBN: 978-81-930411-5-4

Asia Pacific Journals

comprise different formats like

hypermarkets, supermarkets and

convenience stores and non-store formats

like online retailing.

\section{Major product segments in Indian retail}

The product segments cover a wide gamut and it consists of jewellery, apparels, electronics etc. The comparison is made by choosing South Africa as the benchmark as against the more popular Dubai, Singapore, UK or USA because of the following reasons.

- South Africa is an emerging economy, very similar to India in many aspects. E.g $44 \%$ of RSA population lives below the poverty line as compared to $37 \%$ in India.

- South Africa is a multi-religion, multi-ethnic and multi-cultural society like India.

- Like India, South Africa also faces urbanization and infrastructure pressures

\section{Government Policy on Organized Retail}

There is an absence of specific legislation to control the distribution trade, however Baral and Satapathy cites the existence of barriers for the interstate movement of goods because of multiple laws in force at the central, state and local levels governing the retail sector. All retailers are mandated to follow the general rules pertaining to establishment of stores and conduct of activities viz. Shop and establishment act, standards of weights and measures act, provisions of contract labour act, income tax act, customs act, companies act. Some examples of specific state rules for organized retailers include $10 \%$ surcharge imposed by the Tamilnadu Government on organized retailers, Mall developers in West Bengal are asked by the state government to reserve $10 \%$ space for unorganized retailers. 
There is an absence of a single window clearance facility and organized retailers are forced to approach various local bodies to get their approval to carry out their business.

Government Policy on FDI in Organized Retail

The Indian Government under the United Progressive Alliance (UPA) regime in January 2012 approved reforms for singlebrand stores, welcoming anyone in the world to innovate in the Indian retail market with 100\% ownership, but imposed a requirement that the retailer should source $30 \%$ of its goods from India. In December 2012, The Indian government approved 51\% FDI in multi-brand retail with the same requirement as in single-brand retail to source $30 \%$ of its goods from India.

\section{Pan India Supports Organized retail reforms}

The state governments of nine states in India and two union territories as shown in table have expressed their support for the implementation of FDI policy in Retail.

\begin{tabular}{|l|l|}
\hline \multicolumn{2}{|c|}{ States } \\
\hline Andhra Pradesh & Assam \\
\hline Delhi & Haryana \\
\hline Kashmir & Maharastra \\
\hline Manipur & Uttarakhand \\
\hline \multicolumn{2}{|c|}{ Union Territories } \\
Daman and Diu & Dadra and Nagar Haveli \\
\hline
\end{tabular}

Table: Governments supporting FDI in retail

Source: Press Information Bureau, GOI

All the states and union territories that support FDI in retail have mutually consented to the following terms to enable smooth functioning organized retail in their respective states.

- Retail sales outlets may be set up only in cities with a population of more than 10 lakh as per 2011 Census and may also cover an area of $10 \mathrm{kms}$ around the municipal/urban agglomeration limits of 
such cities; retail locations will be restricted to conforming areas as per the Master/Zonal Plans of the concerned cities and provision will be made for requisite facilities such as transport connectivity and parking; In States/ Union Territories not having cities with population of more than 10 lakh as per 2011 Census, retail sales outlets may be set up in the cities of their choice, preferably the largest city and may also cover an area of $10 \mathrm{kms}$ around the municipal/urban agglomeration limits of such cities. The locations of such outlets will be restricted to conforming areas, as per the Master/Zonal Plans of the concerned cities and provision will be made for requisite facilities such as transport connectivity and parking.

- At least $50 \%$ of total FDI brought in shall be invested in 'backend infrastructure' within three years of the induction of FDI, where 'back-end infrastructure' will include capital expenditure on all activities, excluding that on front-end units; for instance, back-end infrastructure will include investment made towards processing, manufacturing, distribution, design improvement, quality control, packaging, logistics, storage, warehouse, agriculture market produce infrastructure etc. Expenditure on land cost and rentals, if any, will not be counted for purposes of backend infrastructure.

Payment system is also an important breakthrough development to trigger organized retailing system. Basically Brick and Mortar is operating on cash and carry model. But whereas organized retailing is doing payments by adopting various other means. They are as follows: 
1) Online ordering and payment through internet banking

2) Through credit cards and debit cards with One Time Password or PIN (personal identification number)

3) Meal passes such as Sodexo, Dining etc.., to purchase food items

4) EMIs to give instalment purchases

5) Mobile wallets

6) Well connected VISA and Master networks which enables people with better connectivity of ATMs for cash withdrawals

\section{CHALLENGES FACED BY THE ORGANIZED RETAILERS IN INDIA}

- Shortage of skilled manpower - Frontend/retail assistant profiles in stores form a major proportion of the employment in the retail sector while store operations account for $75-80 \%$ of the total manpower employed in the organized retail sector. Unfortunately, there are very few courses specific to the retail sector and graduates/post graduates from other streams are recruited. Further, retail training opportunities such as niche courses for areas like merchandising, supply chain and so on are limited.

The condition is more alarming in the unorganized sector where the manpower is not equipped with even the basic level of retail specific and customer service skills, which adds to their incompetence vis-à-vis the organized sector.

- Lack of industry status - Due to the absence of industry specific norms, organized retail in India faces difficulties in getting finance and fiscal incentives.

- Policy induced barriers - Organized retail in India is managed by both the Ministries of Commerce \& Consumer Affairs. While the Ministry of Commerce takes care of the retail policy, the Ministry of Consumer Affairs regulates retailing in 
terms of licenses and legislations.

- Investment Climate - In the latest 2014

Global Retail Development Index (GRDI)

that looks at measures for retail investments worldwide published by management consulting firm AT Kearney, India has slipped to the 20th rank among the top 30 developing countries identified in the report. In the 2013 GRDI, India stood at number 14. This is a grave concern in terms of the investment climate India is projecting to investors to invest in India retail sector [15].

- Real estate - Lack of sophisticated retail planning is another major challenge the sector faces. Available space is easily interchangeable between commercial and retail use. In most cities, it is difficult to find suitable properties in central locations for retail, primarily due to fragmented private holdings, in-frequent auctioning of large government owned vacant lands and litigation disputes between owners.
- Changing lifestyles and consumer behaviours - Rapid urbanization, an expanding middle class, rising incomes and spending power coupled with a majority of youth in total population, triggers to a new consumption pattern. Consumers have become choosier and they prefer variety on the products they buy these days which mandate the retailers to prioritise on customer satisfaction both in terms of product and service. This is leading to mass customization and silent revolution called consumerism.

\section{STRATEGIES FOR IMPROVEMENT}

- According to current available estimates, the retail sector contributes to $8 \%$ of the employment in the country. The modern retail/retail services sector has the potential of creating over 2 million new (direct) jobs within the next 6 years in the country (assuming only $8-10 \%$ share of organized retailing). A cohesive effort 
to develop skills within the sector can have a significant potential impact on productivity and competitiveness, both within the sector and on the wider economy. A strong retail front-end can also provide the necessary fillip to agriculture \& food processing, handicrafts, and small \& medium manufacturing enterprises, creating millions of new jobs indirectly.

- The Government should grant the much needed 'industry status' to the sector by implementing industry specific norm that is uniform throughout the country so that the SOPs that comes with it will help to promote both big and small retailers.

- There is a need to govern retail operations through a single apex body. A single agency can take care of retail operations more effectively, especially with regard to addressing the grievances of retailers. The development of the retail sector can take place at a faster pace if a comprehensive legislation is enacted.

- Retail is still hindered by high consumer price inflation, currency fluctuations, high current account deficits, government debts and strict foreign direct investment policies that have long been an impediment to growth. There is a need of strong government intervention in framing policies in these areas.

\section{CONCLUSION}

"Buyer Beware": India is still at a nascent stage with respect to organized retail and several emerging economies have gone ahead and reaped the benefit of modern retail. India has few retail segments that have higher trading densities than some of these emerging economies and it offers immense potential to organized retailers to 
tap those segments profitably. The

government policies are not favorable for creating a conducive investment climate, this is a source of grave concern and it should addressed with no further delay to lose out on the benefits of foreign investments into the retail sector.

\section{REFERENCES}

1. Bhatia, K.(2014).Changing the face of Indian Retail - Issues and Prospects, SSPS-IJBMR, 1,1,131-141.

2. Emerging global economic situation: Opportunities and policy issues for services sector. Department of Economic Affairs, Ministry of finance, January 2014.

3. Kamal., Kumar, A. (2014). Retail sector: growth and challenge perspective in India. International journal on Emerging Technologies, 5(1), 69-73.

4. Sikri, S., Wadhwa, D. (2012). Growth and Challenges of Retail Industry in India: An Analysis. Asia Pacific Jourmal of Marketing and Management Review, 1(1), $2319-2836$.

5. Talreja, M., Jain, D. (2013). Changing Consumer Perceptions towards
Organized Retailing from Unorganized Retailing- An empirical analysis. International Journal of Marketing, Financial services and Management Research, 2(6), 73-85

6. www.dnb.co.in/indianretailindustry/over view.asp

7. Asipac. (2010). Trading Densities of Organized Retail Formats. Bangalore.

8. Rahman, T. (2012). Organized Retail Industry in India - opportunities and Challenges. International Journal of Research in Finance and Marketing, 2 (2), $82-94$.

9. Baral, S, K., Satapathy, S, K. (2012). A Perspective on Foreign Direct Investment in Multi-brand Retail Sector. Radix International Journal of Banking, Finance and Accounting, 1(11), 